Volume 9, No.1.4, 2020

International Journal of Advanced Trends in Computer Science and Engineering

Available Online at http://www.warse.org/IJATCSE/static/pdf/file/ijatcse7091.42020.pdf

https://doi.org/10.30534/ijatcse/2020/7091.42020

\title{
Modelling of Photovoltaic, Fuel Cell and Battery Hybrid System Connected to Non-Linear Load
}

\author{
Mohd Na'im Afandi Mohd Azami ${ }^{1}$, Nor Aira Zambri ${ }^{2 *}$, Mohd Noor Abdullah ${ }^{1}$, Norhafiz Salim ${ }^{3}$, \\ Sim Sy $\mathbf{Y i}^{2}$, Faridah Hanim Mohd Noh $^{2}$, Farahiyah Mustafa $^{2}$, Norain Sahari ${ }^{2}$ \\ ${ }^{1}$ Faculty of Electrical \& Electronic Engineering, Universiti Tun Hussein Onn Malaysia Johor, Malaysia \\ ${ }^{2}$ Faculty of Technology Engineering, Universiti Tun Hussein Onn Malaysia, Malaysia \\ ${ }^{3}$ Faculty of Electrical and Engineering, Universiti Teknikal Malaysia Melaka, Malaysia \\ *aira@uthm.edu.my
}

\begin{abstract}
Renewable energy is one of the best solutions to solve the energy problem crisis due to the rapid depletion of conventional resources. Photovoltaic (PV) is one of the most promising renewable energy resources which can also be used as the backup power supply for a hybrid electrical system. PV with the support from a fuel cell as a main power supply due to its constant output power can be a viable power source coupled with a battery that can act as an energy storage and a backup power source to limit the usage of the fuel cell to reduce the cost. This hybrid system is connected to a non-linear DC load in order to analyse the ability of this system to supply sufficient power required by the load, to analyse the power switching between each sources and to observe the charging and discharging conditions for the battery. The aim of this project is to develop the photovoltaic, fuel cell and battery hybrid system connected to a non-linear load using MATLAB/Simulink. To ensure the power produced is equal to power required, the boost and buck-boost converters are used to step up and step down the voltage accordingly that is connected with a DC bus. The results show that the proposed hybrid system able to supply the load sufficiently.
\end{abstract}

Key words : PEMFC, Photovoltaic, Fuel Cell, hybrid system, energy storage.

\section{INTRODUCTION}

Currently, renewable energy has become very popular around the world as the basic source of energy production where previous fuel source such as coal, fossil fuels and others has been vastly depleted. Additionally, energy production from conventional fuel sources causes air pollution and the depletion of the ozone layer due to it further creates more damage to nature. Among the most appropriate and preferred alternative way is to use renewable energy resources such as wind, solar and water. Between these three resources, solar power is the most promising source since it can be developed with a lower cost now rather than using wind turbines and hydroelectric dams. However, the use of solar systems does not promise permanent energy output because in some areas of the world does not emit enough sunlight to produce the output that is desired other than the intermittency power itself. Normally, additional power supplies such as fuel cells and battery are used to sufficiently support the energy output to the loads [1]. Photovoltaic cells are connected in a series and/or in a parallel circuit that expresses the desired voltage, current and power levels. Photovoltaic module comprising of PV cell circuits is supplied into a laminate is used in order to protect the environment, and it is considered as the basic building block of the PV systems. Currently, PV is widely used in domestic and industrial applications. However, the weakness of using PV is the power intermittency and it is highly dependent on weather conditions and also solar irradiation [2]-[3]. To overcome the intermittency of power from PV, Proton Exchange Membrane Fuel Cells (PEMFC) is used to solve this problem. Fuel cells (FC) is an electrochemical device that produces direct current electricity through the reaction of hydrogen and oxygen in the presence of an electrolyte disorders. They are an attractive option that is to be used with intermittent sources like PV generation due to the alternating high-efficiency, quick response burden, change in tone, and its fuel flexibility. Unlike batteries, FC does not require charging. The possibility of them in coordination with the PV system has managed to show a grid application related nor stand-alone. Other advantages of FC will be due to its reusability of heat exhaust, on-site installation, and fuel diversity. Fuel for the FC is hydrogen or any other hydrogen-containing compound that can produce hydrogen. The use of the electrolysis reaction to produce hydrogen from water is an effective method that can be used in a small to large scale [2].

PV system is the best power sources because it produces zero pollution to the environment. Additionally it is also renewable, silent, modular and it requires short duration of installation. It is also low impact and easily integrated into 
any architectural structure which makes the best choice for addressing the issues and problems of the depletion of fossil resources [4]. Fuel cells are a selection of the best alternative which will be connected with the PV systems due to its low environmental impact, where it has no noise and emission characteristics. However, it has a temporary slow response time and it has a slow output power with an addition that the FC can trail the load effectively. To ensure it provides a good voltage support, the hybrid system should be connected with a fast respond energy storage unit such as battery or supercapacitor [5].

\subsection{Photovoltaic Generator}

A PV generator can be defined as an energy source or a power plant which is able to directly convert solar energy to electricity. This can be done by taking a couple of arrays which contains modules connected in a series and/or in parallel. PV module is a single unit that is installed from the related series of solar cells. A series of connection of two or more modules is known as a PV string. To prevent backflow of current from the battery, removal such as load sinus, blocking Diode is used and it is usually connected to each string [6]. Like a Diode, solar have the P-type and N-type separated by PN junction. When the PN junction is exposed directly to photons of light with enough energy, the electron carries negative charges produced in the P-type region and a positive charge carrier produced in the $\mathrm{N}$ types regions. Current trends opposed to electron flow direction. The current is light photons that are generated during the process [6].

\subsection{Fuel Cell}

Fuel Cells have been popular in recent years and it gains more attention because of its promising source in technology for power generation. An increase in demand of fuel cell usage is due to its high efficiency characteristics where it is higher than conventional power plants and also because its zero pollution emission [7]. There are many types of fuel cells, consist of anodes, cathodes and electrolytes that allows positively charged hydrogen ion (Proton) to move between the two sides in fuel cells. The reason is due to the cathode catalyst, oxidation reactions proton (regular hydrogen positive ions) and electrons. In cathodes other catalysts cause hydrogen ions, electrons and oxygen that reacts to form water. Fuel cells are classified by the type of electrolyte used and with a starting time difference between 1 second for proton membrane fuel cells (PEM fuel cell or PEMFC) up to 10 minutes for solid oxide fuel cells (SOFC). Individual fuel cells produce relatively small electrical potential, which is about 0.7 volts, hence cells are placed in series, to create sufficient voltage to meet application requirements.

\section{METHODOLOGY}

The purpose of this project is to develop a model of a hybrid system using PV, Fuel Cell and Battery for a stand-alone application. To develop this model, MATLAB/Simulink software has been chosen to construct a circuit simulation. The first step is to conduct a simulation circuit and connecting all the elements that is required in this system such as a PV system, Fuel Cell Stack, DC-DC Boost Converter, DC-DC Buck Boost Converter, DC Bus and Lithium Ion Battery. Next, the complete model will be simulated to ensure the circuit is running perfectly and to gain the result as expected. In this section, all the mathematical equation are included for several elements.

\subsection{Modeling of Photovoltaic, Fuel Cell and Battery}

The block diagram model consist of seven main parts which are the photovoltaic panel, fuel cell, battery, DC-DC Boost Converter, DC-DC Buck Boost Converter, DC Bus and NonLinear load as shown in Figure 1. The PV panel and fuel cell are connected to DC-DC Boost Converter, while the Batteries are connected to DC-DC Buck Boost Converter. Then both converter and Non-Linear loads are connected to each other using a DC Bus. The PV panel and fuel cell will be the main supply source to the load and the DC-DC Converter will become a power management for PV, Fuel Cell and Battery. DC bus function is to allow the connection between the converters to the load. The arrow represent the power flow in this hybrid system.

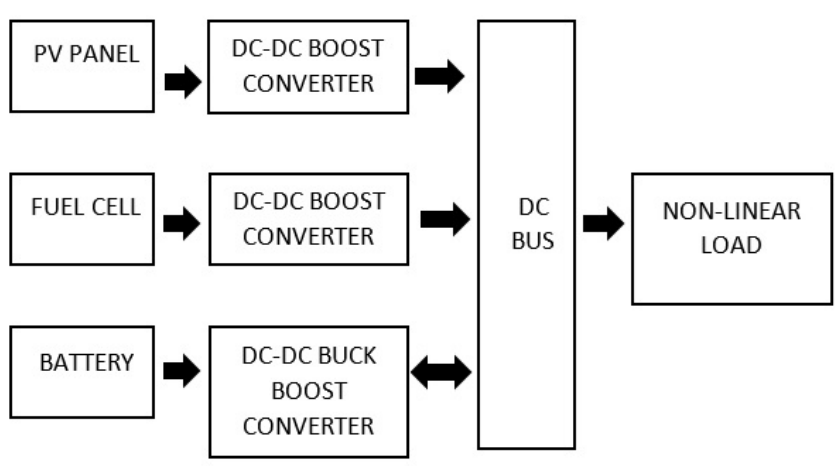

Figure 1: Block Diagram Modeling of Photovoltaic, Fuel Cell and Battery Hybrid System Connected to Non-Linear Load

Figure 2 shows the flowchart of the power management for the hybrid system model. In this model, there are three types of energy sources which are the PV system, battery and fuel cell. Considering the initial condition of each sources is at full power, which means that the battery is fully charged and the $\mathrm{PV}$ panel is at full power of $1000 \mathrm{~W} / \mathrm{m}^{2}$ irradiance. At the starting period of the simulation, the PV system and battery are ready to deliver its power as required by the load. When the load power is higher than zero, PV panel will start to deliver power to the load. However, the PV panel power is being limited by the rate of the block limiter to replicate the intermittency conditions. This situation will cause the power delivered by the PV panel is insufficient to be delivered to the load. Then the battery will deliver its power to help the PV 
panel by delivering the remaining power. The PV power is dependent on the irradiance level. When the irradiance level is drop to $1 \mathrm{~W} / \mathrm{m}^{2}$, the PV panel power will drop to zero and it's unable to deliver power to supply the load. Therefore, the fuel cell will deliver power to the load to ensure continuous supply of power based on the load demand. The power switching between PV panel and fuel cell is control by a switch that will be triggered based on the level of irradiance. Then, the power is delivered by the fuel cell. However, fuel cell has its own rating and unable to deliver load exceeding the power rating. Therefore, the battery will be discharged to help the fuel cell to supply the remaining power to the load. Lastly, when the fuel cell power reaches zero, the required power is fully delivered by the battery. The process ends when the battery power reaches zero.

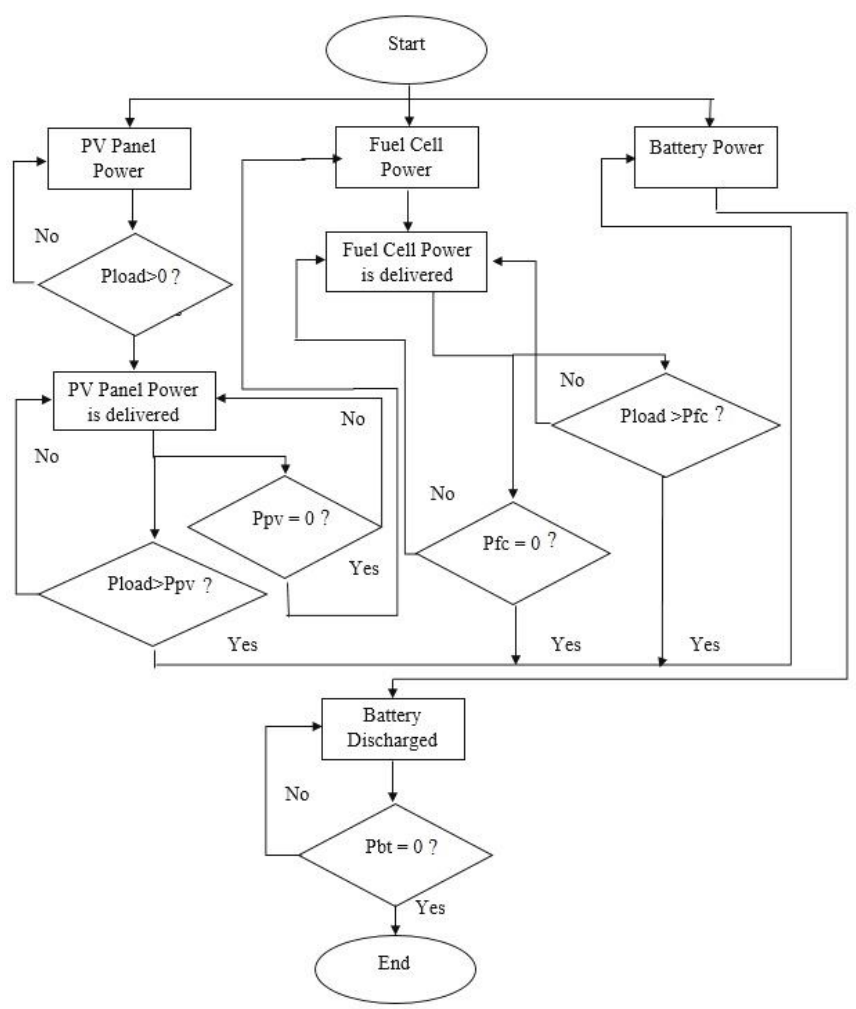

Figure 2: Power Flow of the PV panel, Fuel Cell and Battery Hybrid System

There are four equations that is required for creating each subsystem and it involves the completion of this project. These equations are used to develop the block diagram in the MATLAB Simulink and creates the system for the Photovoltaic (PV) module. The equations and abbreviations involved in this project are[8]:

$$
\begin{aligned}
& I_{p h}=\left[I_{s c r}=\left(K_{i} \times\left(T_{a} K-T_{r} K\right)\right) \times\left(\frac{S}{1000}\right)\right] \\
& I r s=\frac{I s c r}{e\left(\frac{q \times V o c}{K \times N s \times A \times T r k}\right)-1}
\end{aligned}
$$

$$
\begin{aligned}
& I_{d}=I_{r s} \times\left(\frac{T_{a} K}{T_{r} K}\right)^{3} \times e\left[\left(\frac{E_{g} \times q}{K \times A}\right) \times\left(\frac{1}{T_{r} K}-\frac{1}{T_{a} K}\right)\right] \\
& I_{p v}=N_{p} \times I_{p h}-N_{p} \times I_{d} \times\left\{\begin{array}{l}
\left.\left[\begin{array}{l}
\left(\begin{array}{l}
q \\
N_{s}
\end{array}\right) \times A \times K \times T_{a} K \\
\times\left(V_{p v}+I_{p v} \times R_{s}\right)
\end{array}\right)\right]-1
\end{array}\right\}
\end{aligned}
$$

Where,

$$
\begin{aligned}
& I_{O} \quad=\text { Output Current, A } \\
& V_{O}=\text { Output Voltage, } \mathrm{V} \\
& T_{r} k=\text { Reference Temperature }(\mathrm{K}) \\
& T_{a} K=\text { Module Operating Temperature (K) } \\
& S=\text { PV Module Illumination, } \mathrm{kW} / \mathrm{m} 2 \\
& q=\text { Electron Charge }\left(1.6 * 10^{-19} \mathrm{C}\right) \\
& A=\text { Ideality Factor (1.3) } \\
& K=\text { Boltzman Constant }\left(1.3805^{*} 10^{-23} \mathrm{~J} / \mathrm{K}\right) \\
& E_{g} \quad=\text { Band Gap of Si } \\
& I_{S C R}=\text { Short Circuit Current at STC, A } \\
& I_{S C}=\text { Short Circuit Current, A } \\
& V_{O C}=\text { Open Circuit Voltage, } \mathrm{V} \\
& V_{P M}=\text { Voltage at MPP, } \mathrm{V} \\
& I_{P M}=\text { Current at MPP, A } \\
& P_{\text {max }}=\text { Power at MPP, W } \\
& N_{S}=\text { Number of Cells connected in Series } \\
& N_{P}=\text { Number of Cells connected in Parallel } \\
& K i=\text { Short Circuit Temperature Coefficient } \\
& \text { at } I_{s c} \text { at } 0.0013 \mathrm{~A} /{ }^{\circ} \mathrm{C} \\
& R_{S} \quad=\text { Series Resistance of PV Module, Ohm } \\
& I_{p h}=\text { Light Generated Current of the PV Module, A } \\
& I_{P V}=\text { Module of Output Current, A } \\
& \text { Id = PV Module Saturation Current, A } \\
& I_{r s} \quad=\text { Reverse Saturation Current, A }
\end{aligned}
$$

\subsection{PEM Fuel Cell Model}

In this project, the PEM fuel cell is used. For PEMFC, hydrogen is used to generate electricity from the fuel cell system. The power generated is expressed as a function of partial pressure (p) and molar flow rate (q) of gases and water [9]-[11].

$\frac{q H_{2}}{p H_{2}}=\frac{K_{a n}}{\sqrt{M} H_{2}}=K_{2}$

molar mass of hydrogen $(\mathrm{kg} / \mathrm{kmol} / \mathrm{s})$. The relationship between the consumption of hydrogen, which reacted with the current fuel cell systems $\left(\mathrm{I}_{\mathrm{FC}}\right)$ is given by the electrochemical equation.

$q^{r} H_{2}=\frac{N_{O} \times I_{f c}}{2 . F}=2 K_{r} I_{F C}$

The partial pressure of hydrogen gas is given by the equation

$$
P H_{2}=\frac{K H_{2}}{1+T_{H 2^{s}}} \times\left(q_{i n} H_{2}-2 K_{r} I_{f c}\right)
$$


Time constant of hydrogen, $\mathrm{TH}_{2}=\frac{V_{a n}}{\mathrm{KH}_{2} R T}$

Where,

$R=$ universal gas constant $(\mathrm{kmol} / \mathrm{s} \cdot \mathrm{atm})$

$T=$ Absolute temperature $(\mathrm{K})$

Similarly, the partial pressure of water and oxygen can be written. The output voltage of fuel cell system is expressed as the sum of voltage (E),[9]-[10].

$$
\begin{aligned}
& V_{\text {cell }}=E+\eta_{\text {act }}+\eta_{\text {ohmic }} \\
& \eta_{\text {act }}=-B \times \ln \left(C \times I_{f c}\right) \\
& n_{\text {ohmic }}=-R_{\text {int }} \times I_{f c}
\end{aligned}
$$

$$
E_{o}=N_{o} \times\left[E_{o}+\frac{R T}{N F} \times \log \left(\frac{p H_{2} \times \sqrt{p_{O_{2}}}}{p_{\mathrm{H}_{2} \mathrm{O}}}\right)\right]
$$

where $B$ and $C$ are constants, $E_{O}=N_{O}$ load voltage $(\mathrm{V}), N_{O}=$ Number of series cells and $F=$ Faraday's constant $(\mathrm{C} / \mathrm{kmol})$.

\subsection{Battery Model}

In this paper, a lithium ion battery is used as the energy storage model because it is widely used in electrical power applications. The function of the battery in this project is to supply the load in order to sustain the lack of power produced by the main power supply source. Figure 3 shows the equivalent circuit of Lithium Ion battery model. The circuit consist of a combination of two resistors, one capacitor and one voltage source. The parameters of the equivalent circuit can be modified to represent the battery type based on its discharge characteristic [12].

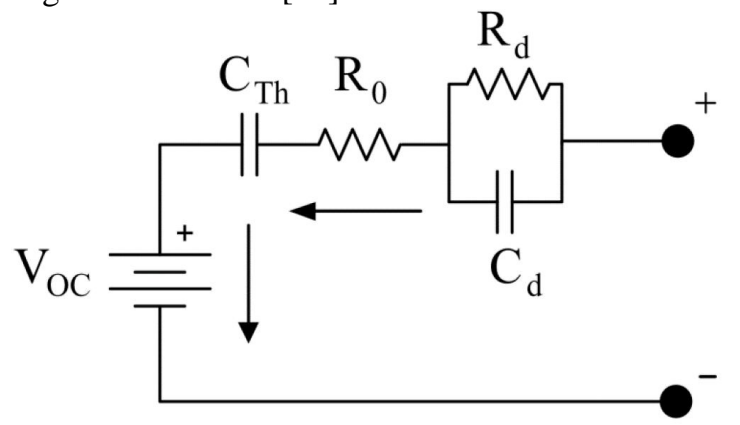

Figure 3: Equivalent Circuit of Li-Ion Battery [13]

\subsection{Boost Converter}

The integration of renewable energy plant into power system leads to the rise of power electronic converters' usage [14]. Step-up chopper or known as Boost Converter is a power converter that steps-up the voltage while stepping down the current. Boost converter normally used with renewable energy due to its lower current rating for power switches and gate drivers [15]. It contains at least two semiconductors which is the diode and the transistor and at least one of the storage elements such as a capacitor, inductor or it could be both. Filters are made of capacitors but sometimes it is a combination of inductors which is normally added to converters output and input to reduce voltage ripple [16]. In this project, the boost converter is used to step up the voltage value of the fuel cell and directly connect to the DC bus. Figure 4 shows the circuit diagram of basic boost converter.

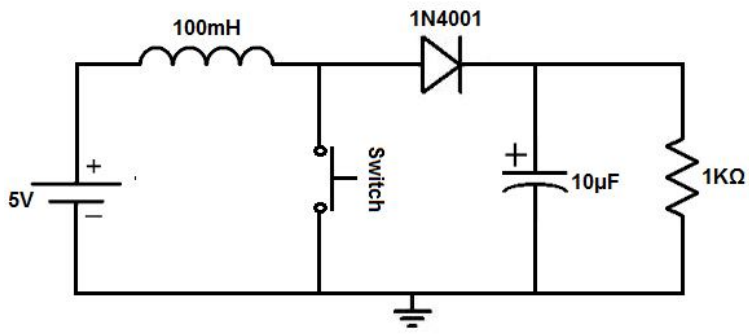

Figure 4: Basic Circuit of Boost Converter [16]-[17]

\subsection{Buck-Boost Converter}

The buck-boost converter model which was developed in MATLAB is shown in Figure 5. The components in the model are inductor, battery, DC bus, and two MOSFET. The operation of MOSFET 1 and MOSFET 2 are similar with the MOSFET in the boost converter model. The turning ON and OFF conditions of the MOSFET gate input is controlled by a switch block. The switch block has 3 inputs. The first input is the data input that is connected with a constant value which is zero. The second input is the controlled input that will control the switch position which is connected to the load power. The third input is also the data input that is connected to the output of the relational operator block. If the load power is less or equal to zero, the input 1 of the switch will operate. Therefore, MOSFET is in OFF condition. The MOSFET is in ON condition when the load power is more than zero and the input 3 of the switch will be on. When MOSFET 1 is ON and MOSFET 2 is OFF, the battery current will flow through the inductor and MOSFET 1 and will operate as a buck converter to charge the battery. When MOSFET 1 is OFF and MOSFET 2 is $\mathrm{ON}$, the current flow through the inductor, MOSFET 2 and the DC bus operates as the boost converter and the battery will discharge.

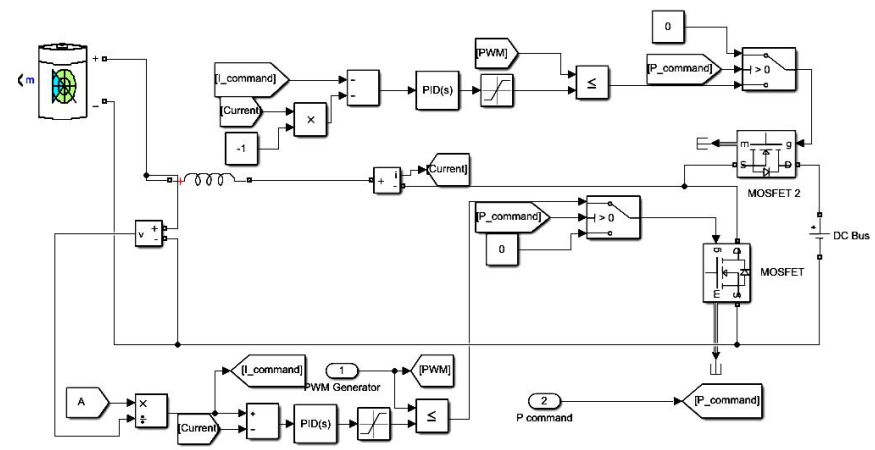

Figure 5: Buck Boost Converter Circuit Connect with DC bus and Battery 


\section{RESULTS AND DISCUSSIONS}

This section will explain the result of the simulations of the hybrid system using Photovoltaic, Fuel Cell and Battery connected to non-linear load. The system has been done in MATLAB/Simulink software.

\subsection{Photovoltaic, Fuel Cell and Battery Hybrid System Connected with Non-Linear Load Model}

The complete simulation model of Photovoltaic, Fuel Cell and Battery hybrid system connected to a Non-Linear load is shown in Figure 6. The PV panel, fuel cell and battery act as the main supply in this model. DC motor act as the non-linear load and the power produced by the PV panel and fuel cell depends on the DC motor power signal. The fuel cell power and the PV panel power is controlled by the rate limiter block which is to limit the power delivered to the DC motor. A switch is used to control the power flow between the PV panel and the fuel cell. When PV irradiance is higher than 900 $\mathrm{W} / \mathrm{m}^{2}$, the switch will allow the PV panel power to be delivered to the load and there will be no power delivered by the fuel cell. Then, when the irradiance level drops to zero, the switch will allow the fuel cell to continue delivering power to the load as the PV panel power reaches zero. The remaining power will be supplied by the battery power. Therefore, more power is supplied by the fuel cell to reduce the usage of battery power. The fuel cell and PV panel are connected to the boost converter to step up the voltage level and the battery is connected to buck-boost converter to step up or step down the battery voltage level. Then all three converters are connected using the DC bus.

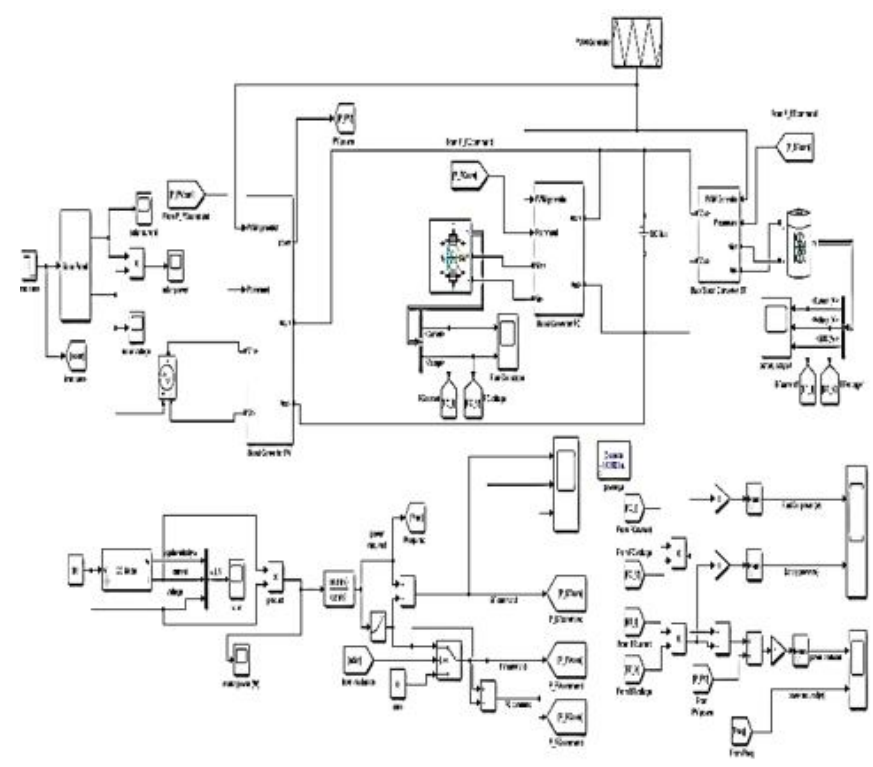

Figure 6: Modeling of PV panel, Fuel Cell and Battery Hybrid System Connected with Non-Linear Load

Table 1 shows the parameters of PV panel, fuel cell, battery, DC motor and DC bus model in MATLAB. The battery voltage is set to $26.4 \mathrm{~V}$ with a rated capacity of $6.6 \mathrm{Ah}$ and an initial state-of-charge is $100 \%$, meaning the battery is fully charged. The fuel cell current input is set to $8 \mathrm{~A}$ and the voltage produced by the fuel cell is $30.01 \mathrm{~V}$. The DC motor input voltage is set to $50 \mathrm{VDC}$ with $20 \mathrm{ohm}$ winding resistor and $0.1 \mathrm{H}$ winding inductance. The $\mathrm{PV}$ panel maximum irradiance is set at $1000 \mathrm{~W} / \mathrm{m}^{2}$ and the minimum irradiance is set at $1 \mathrm{~W} / \mathrm{m}^{2}$.

Table 1: Parameter of PV panel, Fuel Cell, Battery, DC Motor and DC Bus

\begin{tabular}{|c|c|}
\hline Component & Parameter \\
\hline PV panel & $\begin{array}{l}\text { Maximum irradiance: } \\
1000 \mathrm{~W} / \mathrm{m}^{2} \\
\text { Minimum irradiance: } 1 \mathrm{~W} / \mathrm{m}^{2} \\
\text { Internal resistance: } 8.45 \mathrm{ohm} \\
\text { Output voltage: } 42.93 \mathrm{~V} \\
\text { Output current: } 5.08 \mathrm{~A} \\
\text { Output power: } 218.06 \mathrm{~W}\end{array}$ \\
\hline Battery & $\begin{array}{c}\text { Battery type: Lithium Ion } \\
\text { Nominal voltage: } 26.4 \mathrm{~V} \\
\text { Full charge voltage: } 30.73 \mathrm{~V} \\
\text { Rated Capacity: } 6.6 \mathrm{Ah} \\
\text { Initial state-of-charge: } 100 \%\end{array}$ \\
\hline DC motor & $\begin{array}{c}\text { Input voltage: } 50 \mathrm{~V} \\
\text { Winding resistance: } 2 \mathrm{Ohm} \\
\text { Winding inductance: } 0.1 \mathrm{H} \\
\text { Inertia loads moment: } \\
0.1 \mathrm{~kg} \cdot \mathrm{m}^{2} \\
\text { Viscous friction: } 0.01\end{array}$ \\
\hline Fuel cell & $\begin{array}{c}\text { Stack power } \\
\text { Nominal: } 1259.96 \mathrm{~W} \\
\text { Maximal: } 2000 \mathrm{~W} \\
\text { Fuel Cell resistance: } \\
0.061871 \text { ohms } \\
\text { Nerst voltage of one cell: } \\
1.115 \mathrm{~V} \\
\text { System temperature [T]: } 328 \\
\text { kelvin } \\
\text { Output Voltage: } 33.55 \mathrm{~V} \\
\text { Output Current: } 8.647 \mathrm{~A} \\
\text { Output Power: } 290.1 \mathrm{~W}\end{array}$ \\
\hline DC Bus & Bus voltage: $42 \mathrm{~V}$ \\
\hline
\end{tabular}

3.2 Simulation Results of Photovoltaic, Fuel Cell and Battery Hybrid System Connected with Non-Linear Load

The PV panel, fuel cell and battery hybrid system connected to non-linear load model is analysed for $5 \mathrm{~s}$. The results of the load power, hybrid power, PV panel power, battery power, fuel cell power, battery state-of-charge are obtained from the simulation. The result of PV panel, fuel cell and battery hybrid power and DC motor power versus time is shown in Figure 7. At the period of 0s until $0.2 \mathrm{~s}$, the DC motor power increases dramatically until it reaches its maximum power at $1168 \mathrm{~W}$ due to its high starting current that is required to run the DC motor. Next, at the period of $0.3 \mathrm{~s}$ until $5 \mathrm{~s}$, the power starts to decrease slowly because during this time, the motor 
current reached its full load current state. From the results, the total power delivered by the PV panel, fuel cell and battery is $290.1 \mathrm{~W}$. The fuel cell produced an excess of power to deliver power to the load and chargers the battery. This results show that the power produced by the hybrid system is able to supply enough power that is required by the load. However, there is a spike occurs for a short period that was caused by the power switching between PV power and fuel cell power. The behaviour of PV panel power, battery power and fuel cell power versus time is shown in Figure 8. At the beginning of the simulation, the PV panel delivers power to the loads but the PV power is limited and it is insufficient to supply the load, battery power is then discharged from its full state-of-charge to support the PV panel power to ensure the power produced is enough to supply the load. The battery power is discharged and increased dramatically to its maximum power at $1168 \mathrm{~W}$ to support the starting torque needed to start the motor. Then the battery power is decreased to $-0.32 \mathrm{~W}$ at $1.5 \mathrm{~s}$ duration. The battery is charged for a short period of time until it reaches a duration of $3.5 \mathrm{~s}$ and remains at rest at $0 \mathrm{~W}$ until $5 \mathrm{~s}$. The fuel cell remained at rest from 0 s until it reaches $2 \mathrm{~s}$ and then increases from 0 till $580 \mathrm{~W}$ because in this duration the switch has allowed the fuel cell to deliver power to the load. Fuel cell power is slowly decreased while it charges the battery and supplies the load in the same time until it reaches $3.5 \mathrm{~s}$, then the fuel cell power remains constant at $290.1 \mathrm{~W}$ to deliver power to the load until it reaches 5s. PV panel power constantly increases from $0 \mathrm{~W}$ till $580 \mathrm{~W}$ at $2 \mathrm{~s}$ and then drop to $0 \mathrm{~W}$ because during this duration, the irradiance was dropped to $1 \mathrm{~W} / \mathrm{m}^{2}$. The combination of power by this three sources has produced hybrid power that is sufficient for the DC motor load.

Figure 7: Result of PV Panel with Hybrid System and the Load
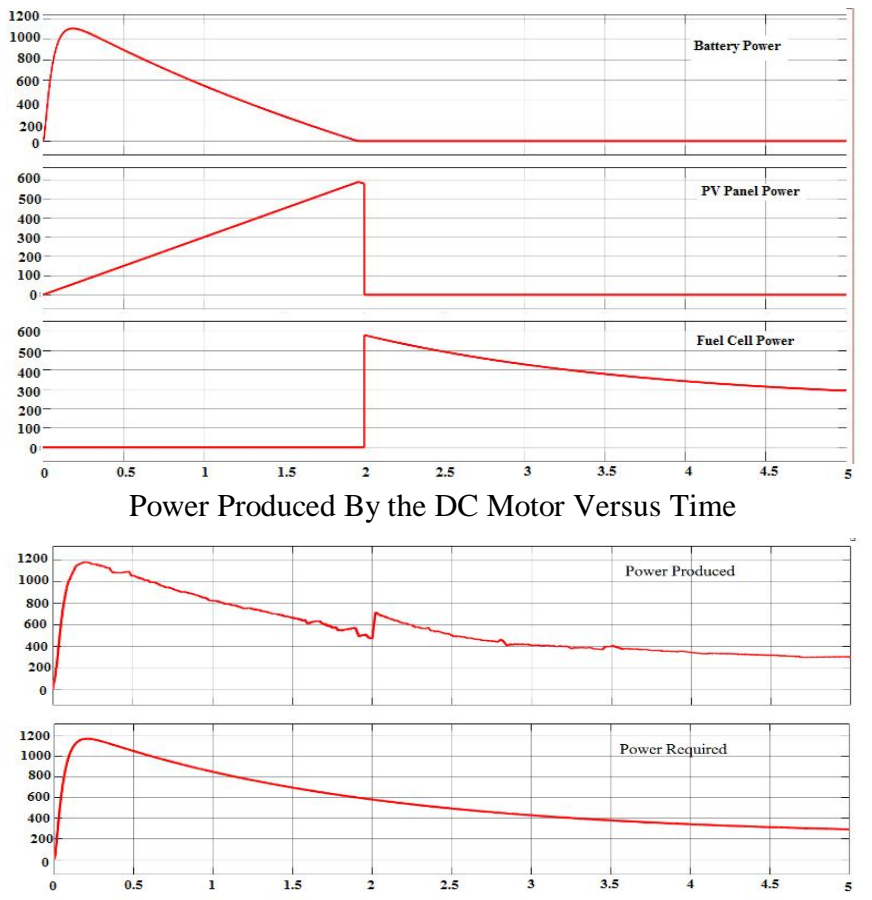

Figure 8: PV Panel, Fuel Cell and Battery Power Behaviour versus Time

\subsection{Battery Charging and Discharging Condition}

Figure 9 shows the result of the fuel cell power and battery power. The fuel cell power remains at rest at $0 \mathrm{~s}$ and starts to increase from $0 \mathrm{~W}$ to $580 \mathrm{~W}$ at $2 \mathrm{~s}$ and slowly decrease while it charges the battery and delivers power to the load until it reaches $290.1 \mathrm{~W}$ at $5 \mathrm{~s}$. The battery power increases dramatically to support the PV panel power because of the intermittency condition of PV panel. At $2 \mathrm{~s}$ duration, the battery power drop to $-32 \mathrm{~W}$ until it reaches $3.5 \mathrm{~s}$. It proves that the battery had been charged by the fuel cell with an excess of power for $1.5 \mathrm{~s}$ duration. Then the battery remains at rest until it is at $5 \mathrm{~s}$ because it reaches its fully-charged voltage condition and its state-of-charge is at $100 \%$. Figure 10 shows the details on the reading of the battery power scope to prove that it drops to $-32 \mathrm{~W}$ and it shows that it is in charging condition.

The battery model state-of-charge (SOC) versus time is shown in Figure 11. The initial SOC for battery is set to $100 \%$. At time of $0 \mathrm{~s}$ to $2 \mathrm{~s}$, the SOC of battery decreases extremely due to the power required to start the DC motor. At $2 \mathrm{~s}$, the SOC of battery remains constant because the battery power has gone down to 0 and it needs to be charged by the fuel cell power. At $5 \mathrm{~s}$, the SOC remains at $99.84 \%$. That means the battery only consumed $0.16 \%$ from its fully charged voltage condition within the $2 \mathrm{~s}$ period. Table 2 shows the change of

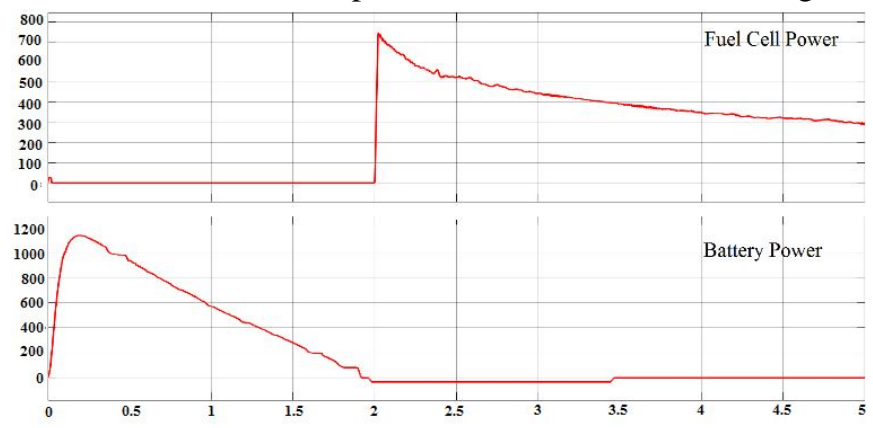

SOC of the battery within 5 seconds in this model. At the initial stage of the simulation, the battery SOC is at $100 \%$. However, at 1 second battery SOC has decrease at $99.9 \%$ and keeps decreasing until it reaches $1.5 \mathrm{~s}$ at $99.84 \%$ and then slightly increases to $99.85 \%$ and remain constant until it reaches $5 \mathrm{~s}$. This result shows that the consumption of the battery can be saved in this hybrid system.

Figure 9: Fuel Cell Power and Battery Power versus Time

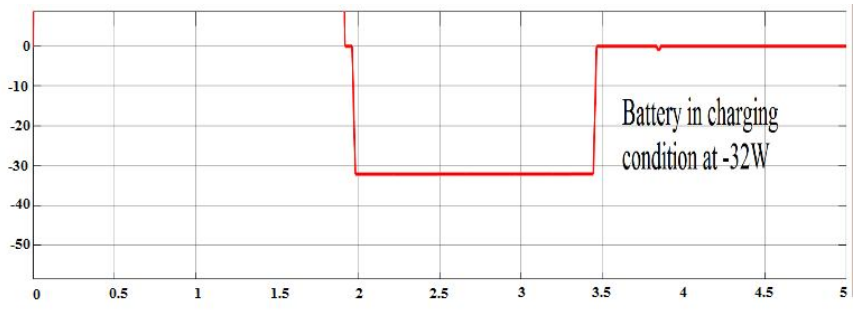

Figure 10: Battery Power in Charging Condition 


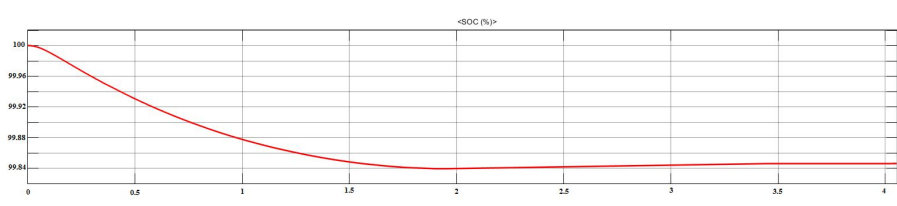

Figure 11: State-of-Charge of Battery versus Time

Table 2: SOC of the Battery

\begin{tabular}{|c|c|c|c|}
\hline Time (s) & $\mathbf{0}$ & $\mathbf{1 . 5}$ & $\mathbf{5 . 0}$ \\
\hline $\begin{array}{c}\text { SOC of battery } \\
\text { for PV panel and } \\
\text { fuel cell hybrid } \\
\text { system model }(\%)\end{array}$ & 100 & 99.84 & 99.85 \\
\hline
\end{tabular}

\section{CONCLUSION}

This paper presents the modelling of PV panel, fuel cell and battery hybrid system that is connected to the non-linear load. For power management, a boost converter and buck-boost converter were used to control the power flow from the PV, battery and fuel cell by controlling the current from each source. The simulation result shows that the combination of PV panel, fuel cell and battery have successfully supplied the power required by the load. The fuel cell power is used to deliver power to the load and to charge the battery with it excess power and then remains constant following the required power value. The battery power are discharge to support the insufficient power during the high load to start the motor and to ensure the power produced by this hybrid system is equal to the power required by load.

\section{ACKNOWLEDGEMENT}

This work was supported by TIER 1 grant (U862) of Universiti Tun Hussein Onn Malaysia (UTHM), Power Energy Focus Group, Advanced Technology Centre (ATC), Faculty of Engineering Technology, UTHM.

\section{REFERENCES}

1. V. K. Maharia, and G. Dalal. Hybrid PV/Fuel Cell System Design and Simulation. International Journal of Science and Research (IJSR), Vol. 3(9), pp. 105-109, September 2014.

2. D. Debika, K. Ajoy, and R. Srimanta. Optimization and Modeling of PV/ FC/Battery Hybrid Power Plant for Standalone Application. International Journal of Engineering Research \& Technology (IJERT), Vol. 01(03), pp. 1-10, May 2012.

3. J. Zhenhua. Power management of hybrid photovoltaic - fuel cell power systems, in 2006 IEEE Power Engineering Society General Meeting, 2006, pp. 6.
4. J. Imhoff, G. F. Rodrigues, J. R. Pinheiro, H. L. Hey. A stand alone photovoltaic System Based On Dc-Dc Converters in a Multi String Configuration, in 2007 European Conference on Power Electronics and Applications, 2007, pp. 1-10.

5. O. C. Onar, M. Uzunoglu, M. S. Alam. Modeling, Control and Simulation of an Autnomous Wind / Turbine / Photovoltaic / Fuel Cell / Ultra-Capacitor Hybrid Power System. Journal of Power Sources, Vol. 185(2), pp. 1273-1283, 2008.

6. T. Markvart. Solar Electricity, John Wiley Sons. N.Y., 2003.

7. L. Tae-Won, K. Sung-Ho, Y. Yong-Ho, J. Su-Jin, and W. Chung-Yuen. A $3 \mathbf{k W}$ fuel cell generation system using the fuel cell simulator, in 2004 IEEE International Symposium on Industrial Electronics, 2004, pp. 833-837.

https://doi.org/10.1109/ISIE.2004.1571921

8. N. S. Jayalakshmi, and D. N. Gaonkar. Modeling and Performance Analysis of Grid Integrated Hybrid Wind and PV Based DG System with MPPT Controllers, International Journal of Distributed Energy Resources and Smart Grids, Technology and Science Publishers, 2010, Vol. 10(2), pp. 115-131.

9. M. Y. El-Sharkh, A. Rahman, M. S. Alam, P. C. Byrne, A. A. Sakla, and T. Thomas. A dynamic model for a stand-alone PEM fuel cell power plant for residential applications. Journal of Power Sources, 2004, Vol. 138, pp. 199-204.

10. M. H. Nehrir, C. Wang, S. R. Shaw. Fuel Cells: Promising devices for distributed generation, IEEE Power and Energy Magazine, 2006, Vol. 4(1), pp. 47-53.

11. H. L. Tsai, C. S. Tu, Y. J. Su. Development of generalized photovoltaic model using MATLAB/SIMULINK, in Proceedings of the World Congress on Engineering and Computer Science WCECS, 2008.

12. W. Han, L. Zhang, and Y. Han. Mathematical modeling, performance analysis and control of battery equalization systems: Review and recent developments. in Advances in Battery Manufacturing, Services, and Management Systems (J. Li, S. Zhou, and Y. Han, eds.), New York: Wiley-IEEE Press, 2016, ch. 12, pp. 281-301.

13. V. Sangwan, V. R. Vakacharla, R. Kumar, and A. K. Rathore. Estimation of state of charge for Li-ion battery using model adaptive extended Kalman filter, in 2017 7th International Conference on Power Systems (ICPS), 2017, pp. 726-731.

14. A. N. Christopher Ngadi, L. N. Muhammad, H. Daniyal, N. Jaalam, N. R. H. Abdullah, and S. A. Ghani. A Comparative Study of Hysteresis Current Controller and PI Controller in Grid-Connected Inverter. International Journal of Advanced Trends in Computer Science and Engineering ( IJATCSE ), Vol. 8(6), pp. 3182-3187, 2019.

https://doi.org/10.30534/ijatcse/2019/83862019 
15. M. A. A. M. Zainuri, E. A. Azari, A. A. Ibrahim, A. Ayob, Y. Yusof, and M. A. M. Radzi. Analysis of Adaptive Perturb and Observe-Fuzzy Logic Control Maximum Power Point Tracking for Photovoltaic Boost DC-DC Converter. International Journal of Advanced Trends in Computer Science and Engineering ( IJATCSE ), Vol. 8(1.6), pp. 201-210, 2019.

https://doi.org/10.30534/ijatcse/2019/3181.62019

16. S. Palanidoss, and T. V. S. Vishnu. Experimental analysis of conventional buck and boost converter with integrated dual output converter, in 2017 International Conference on Electrical, Electronics, Communication, Computer, and Optimization Techniques (ICEECCOT), 2017, pp. 323-329.

17. A. M. Haque, S. Sharma, and D. Nagal. Conventional and switched inductor buck boost converter circuit for solar power system: Simulation, comparison and results, in 2016 International Conference on Electrical, Electronics, and Optimization Techniques (ICEEOT), 2016, pp. 873-878. 